\title{
PROSPECTIVE PRIMARY TEACHERS' VIEWS ON THE NATURE OF SCIENCE
}

\section{Rafael Amador-Rodríguez ${ }^{1}$ iD, Agustín Adúriz-Bravo ${ }^{2}$ (D) Jorge Alberto Valencia-Cobo ${ }^{1}$ (D), Roberto Reinoso-Tapia ${ }^{3}$ (D), Jaime Delgado-Iglesias ${ }^{3}$ iD}

\author{
${ }^{1}$ Institute of Educational Studies-IESE, Universidad del Norte (Colombia) \\ ${ }^{2}$ CeFIEC, Research Institute Center for Training and Research in Science Teaching, \\ Faculty of Exact and Natural Sciences, University of Buenos Aires (Argentina) \\ ${ }^{3}$ University of Valladolid (Spain) \\ ryamador@uninorte.edu.co,aadurizbravo@cefiec.fcen.uba.ar,javalenciac@uninorte.edu.co, \\ robertoreinoso@uva.es, jaime.delgado.iglesias@uva.es
}

Received March 2021

Accepted June 2021

\section{Abstract}

This article presents the results of a piece of research that analyzed the views on the nature of science (NOS) among student teachers enrolled in programs of Primary Education at two public universities in Spain. Previous studies have reported that science teachers maintain 'eclectic' epistemological perspectives on science; in this article, we test if such a hypothesis holds when teachers' NOS ideas are 'anchored' in specific periods and topics of the philosophy of science. We studied 114 prospective teachers attending an undergraduate teaching course with emphasis on the natural sciences at the Universities of Burgos and Valladolid in the period of 2017-18. A Likert-scale questionnaire with 37 items was applied to determine trends in those teachers' epistemological views on science. The results showed that teachers' views are mostly correlated with the philosophical period of Logical Positivism/Received View, and to some extent to the period of Recent and Contemporary Accounts. Regarding the classical epistemological topics of correspondence, methodologies, intervention, evolution and representation, teachers' views could be related to the period of Logical Positivism/Received View and Critical Rationalism, but also to the New Philosophy of Science. The main conclusion of this study is that teachers' expressed views on NOS are epistemologically eclectic to a much smaller degree when examined with more details concerning specific periods and topics of the philosophy of science.

Keywords - Epistemological views, Nature of science, Science teachers, Philosophy of science; Epistemological profile.

\section{To cite this article:}

Amador-Rodríguez, R., Adúriz-Bravo, A., Valencia-Cobo, J.A., Reinoso-Tapia, R., \& Delgado-Iglesias, J. (2021). Prospective primary teachers' views on the nature of science. Journal of Technology and Science Education, 11(2), 403-418. https://doi.org/10.3926/jotse.1271 


\section{Introduction}

An adequate understanding of the nature of science (NOS) is a central component of scientific literacy (Klopfer, 1969; National Science Teachers Association [NSTA], 1982; Prima, Utari, Chandra, Hasanah \& Rusdiana, 2018). In general, the expression "nature of science" refers to the epistemology of science, which addresses the problems related to philosophical assumptions, commitments, values, developments and conceptual inventions in science, consensus in scientific communities, and characteristics and functions of scientific knowledge (Amador-Rodríguez \& Adúriz-Bravo, 2018; Colagrande, Martorano \& Arroio, 2016; Ryan \& Aikenhead, 1992; Tsai \& Liu, 2005).

The available theoretical developments within the research line on NOS generally point to the need to identify epistemological foundations that are both valuable and useful for science education (Izquierdo-Aymerich \& Adúriz-Bravo, 2003). We adhere to the idea that, when aiming at a quality science education for all, it is necessary to explicitly introduce in science classes some instrumental content from the philosophy of science. Such content is what our field of didactics of science (i.e. science education as a discipline) usually calls the "nature of science" (McComas, Almazroa \& Clough, 1998; Flick \& Lederman 2004; Buaraphan, 2012). American scholar William McComas et al. (1998) depict NOS as a "fertile hybrid arena" that combines elements from various meta-science (i.e., scientific disciplines that establish second-order, "meta-discourse" on science). He proposes that contributions to NOS would mainly come from the philosophy, history, and sociology of science. Thus, NOS, from the point of view of didactical research and innovation, can be understood as a line emerging from new curriculum needs: in the formation of citizens, science teaching should combine two important aspects -knowing science and knowing about science (Amador-Rodríguez \& Adúriz-Bravo, 2018).

Authors within the line of research on NOS generally establish connections between teachers' and students' conceptions of science and well-known views coming from the history of professional philosophy of science, such as hypothetical-deductivism, relativism, empiricism, revolutionism, constructivism, axiology, etc. (Cleminson, 1990; Izquierdo-Aymerich \& Adúriz-Bravo, 2003; Mellado \& Carracedo, 1993; Nussbaum, 1983). Educational proposals generally select NOS topics on whose relevance for scientific education there is reasonable consensus among researchers and teachers, for example: scientific method, theory change, realism, scientific explanation, theory-leadenness of observation. The proposals then infuse these topics into classroom activities using various strategies (McComas et al., 1998). One point that needs further research is reflection on the specific role of NOS in science teachers' professional induction.

\section{Teachers' Views of NOS}

A proper comprehension of NOS has been linked to the development of scientific literacy. Studies have shown that teachers' views of NOS are not consistent with recent and contemporary conceptions of the scientific activity (Abd-El-Khalick \& Lederman 2000; Gallagher 1991; Sevim \& Pekbay, 2012). It has been said that teachers do not have a clear idea of the values or assumptions that scientists make in developing scientific knowledge (Morrison, Raab \& Ingram, 2009). According to previous studies, teachers have many misconceptions about NOS and these ideas could pose problems for effective scientific teaching (Jun-Young \& Lederman, 2018; Leinonen, Haaranen, Kesonen, Koponen, Hirvonen \& Asikainen, 2020; McComas 1996; Ucar, 2012), although it has been shown that teachers' conceptions of the nature of science do not necessarily influence all of their classroom practice (Lederman, 1999). It has also been stated that teachers' view about NOS are related to their religious opinions and their adherence to positivist science (Akerson \& Donnelly, 2008). Lin and Chen (2002) state that teachers' views of NOS relate to heavily traditional tenets such as "theories are based directly on observations", "scientific knowledge progresses through accumulation of observations" and "progress consists in discovering theories that represent a closer approximation to absolute truth", which can be located not far away from philosophical positions such as empiro-inductivism, metaphysical realism or ontological positivism. 
Dogan and Abd-El-Khalick (2008) determined teachers' conceptions on the nature of science through a questionnaire administered to 362 science teachers. Participants" responses were categorized as "naïve", "has merit" or "informed". The vast majority of the participating teachers held naive views about some important aspects of NOS, for example: aspects related to the relationship between scientific constructs and reality; the epistemological status of scientific hypotheses, theories and laws, and the relationship between these categories in scientific knowledge; the nature and assumptions underlying the development of scientific theories; and the myth of a universal, step-by-step scientific method. In the work of Torres, Moutinho, Almeida and Vasconcelos (2013), results reveal some naive views regarding NOS questions: all the teachers investigated assumed that scientific knowledge is not definitive; however, they believed that scientific knowledge only changes with new information and technology.

Most of previous research has performed an 'en bloc' epistemological analysis of teachers' views on the nature of science, without nuances in terms of the different core "topics" of professional philosophy of science; many authors have advocated for more epistemological finesse to elicit and characterize NOS in teachers (Irzik \& Nola, 2011; Matthews, 2012).

\section{1. "Periods" of the Philosophy of Science to Model NOS Views}

An alternative perspective on the study of NOS views is provided when a periodization of the philosophy of science is introduced to map those views. A proposal to relate teachers' ideas on NOS with specific philosophical formulations achieves a higher degree of epistemological specificity than previous, more general studies. The periodization used here proposes five periods corresponding to well-established schools in the philosophy of science of the 20th century, selected by their relevance for the research community in didactics of science (Adúriz-Bravo, 2014). The periods are as follows (Amador-Rodríguez, 2018):

1. Logical Positivism/Received View (LP/RV). These two schools of the philosophy of science (active just before and after World War 2) emphasize the methodological aspects of the scientific activity. They favor a 'syntactic' (or logical-linguistic) approach for the study of scientific knowledge; with this formalistic approach they generate rigorous analyses of the structure and validity of such knowledge.

2. Critical Rationalism (CR). This second period in the philosophy of science is well represented in the writings of Karl Popper, who aimed at modifying or refuting the theoretical foundations of logical positivism. He rejected the principle of induction and highlighted the value of theories to oppose to the idea of 'neutral' observation. In this period, scientific progress is interpreted as the recurrent rejection of theories through falsification and their replacement by more satisfactory theories through successive 'conjectures and refutations'.

3. The New Philosophy of Science (NPS). Representatives of this third period (such as Thomas Kuhn) expressed two major interests: studying the historical aspects of science and confronting the basic tenets assumed by mainstream perspectives. As a result of these new epistemological views, alternative methodological proposals emerged. For example, theories came to be seen not as finished axiomatic systems 'frozen' in time, but rather as more or less complex conceptual organisms that develop over time. In addition, the categories of 'paradigm' and of 'program of scientific research', among others, became the units of analysis in order to understand, explain and represent scientific knowledge.

4. Post-Kuhnian Philosophy of Science (PKPS). This perspective confronts the alleged neutrality and objectivity in science. Scientific terms are recognized to be theory-laden, and any observation depends on the theory through which the world is observed. It follows that observational terms do not provide meaning to theoretical concepts but, instead, the latter determine the former. Besides, this epistemological period proclaimed the inexistence of the famous 'scientific method'. 
5. Recent and Contemporary Accounts (RCA). This last period in 20th century philosophy of science (spanning for the last two decades, and continuing into the 21 st century) comprises a plethora of epistemological schools, which coexist with different degrees of harmony and tolerance. For the purposes of this study, only the so-called 'semantic view of scientific theories' will be considered. Adepts to the semantic perspective focus on the meaning and use of scientific theories and only secondarily on their form or structure. Semantic approaches postulate that the relationship between phenomena ('reality') and what science says about them ('representation') is mediated by scientific models as abstract representations of the world (Adúriz-Bravo \& Izquierdo-Aymerich, 2009). Theoretical models and empirical phenomena maintain a relationship of resemblance technically known as 'similarity' (Adúriz-Bravo, 2013).

\section{2. "Topics" of the Philosophy of Science: Aspects of the Scientific Activity as Foci for NOS}

Epistemological topics are structuring ideas about science-in-the-making: they intend to capture essential aspects of the scientific practice (Adúriz-Bravo \& Izquierdo-Aymerich, 2009). Each listed aspect in Table 1 suggests a dimension of study regarding central aspects of NOS.

\begin{tabular}{|l|l|}
\hline \multicolumn{1}{|c|}{ Topic } & \multicolumn{1}{c|}{ Definition } \\
\hline Contexts & Refers to the contexts, spaces or domains where scientific activity takes place. \\
\hline Correspondence & $\begin{array}{l}\text { Describes how theoretical entities (theories, laws, models, hypotheses, among others) relate to } \\
\text { reality. }\end{array}$ \\
\hline Evolution & Refers to proposed models of scientific change. \\
\hline Intervention & $\begin{array}{l}\text { Relates to experimentation, observation and other activities employed in science to generate } \\
\text { knowledge about the world. }\end{array}$ \\
\hline Judgment & Consists of the decisions taken by the scientific community regarding a given theory or model. \\
\hline Languages & $\begin{array}{l}\text { Corresponds to how scientists employ symbolic, semiotic, expressive resources to define, } \\
\text { describe, express and communicate scientific theories or models. }\end{array}$ \\
\hline Methodologies & $\begin{array}{l}\text { Refers to the possible existence of methods as more or less universal and normative rules to } \\
\text { guide scientific activity. }\end{array}$ \\
\hline Rationality & Relates to the criteria used by scientists to evaluate, justify and accept scientific theories or models. \\
\hline Representation & Examines the intellectual tools that scientists construct to represent or model phenomena. \\
\hline Values & Refers to epistemic (and eventually non-epistemic) values guiding scientific activity. \\
\hline
\end{tabular}

Table 1. Epistemological topics for the study of different specific aspects of NOS

\section{Methods}

The purpose of this piece of research is to use the "periods" and "topics" of the philosophy of science presented above in order to elicit and describe the representations about NOS in future teachers for primary education. The hypothesis proposed is that those representations of NOS, when seen through this theoretical lens, are conservative, mostly related to Logical Positivism/Received View.

On the basis of our methodological approach to data analysis, our contention is that each period of the philosophy of science can be understood as a set of theoretical models that theorize on what science is and how it works (see McComas, 1996). Those models are aimed at interpreting distinct central aspects of science as a process and as a product, such as the relations between facts and theories, the modes of reasoning deemed valid by the scientific community, the construction of specific technical languages to 'capture' the world, the diverse contexts in which science is developed, the ways in which scientific theories evolve in time, etc. Such aspects, which we want to 'thematize' in teachers' NOS, provide an exhaustive map of epistemological positions. Thus, a reconstruction of 20th century philosophy of science in five periods dealing with ten aspects proves to be detailed enough to capture the core of prospective teachers' epistemological views (Amador-Rodríguez, 2018). 


\subsection{Participants}

A total of 114 preservice primary teachers (79 women, $35 \mathrm{men}$ ) from two public universities (Burgos and Valladolid) in Spain participated in the study. Participants were enrolled in a course of didactics of science; this was one of the required courses in their teacher education program. The sample was chosen incidentally -students who could be accessed at the time of the investigation were selected. Ninety-three participants were between 21 and 25 years old; 11 were between 26 and 30 years old; ten were 31 years old and above. Results that follow hold for a sample in which 31\% of participants were males and $69 \%$ females. The discussions provided in this report are not related to the category of gender, since, in a first analysis, no clear trends were recognized.

\subsection{Instrument}

The questionnaire includes statements from the five periods of the philosophy of science -Logical Positivism/Received View, Critical Rationalism, the New Philosophy of Science, Post-Kuhnian Philosophy of Science, and Recent and Contemporary Accounts- that were described above. Teachers' degree of agreement/disagreement on a Likert scale was asked. Our measuring instrument for teachers' epistemological views consists of 37 statements representing conceptions in the different topics of the philosophy of science (Table 2): Correspondence (5 items); Representation (5 items); Intervention (5 items); Methodologies (5 items); Evolution (4 items); Judgement (4 items); Languages (3 items); Values ( 2 items); Contexts ( 2 items); and Rationality ( 2 items). Responses to the 5-point Likert-type scale that we used were scored 1 to 5 (i.e. $1=$ Strongly Disagree, $3=$ Neutral/Uncertain, and $5=$ Strongly Agree). Thus, the range of possible scores is from 37 to 185 points. In general, high scores on this scale indicate views closer to Recent and Contemporary Accounts, while low scores point to Logical Positivism/Received View.

When administering our NOS instrument to the sample of 114 preservice primary teachers, they were explicitly told that their performance on the questionnaire would not affect their course grades. This was done in order to lessen biases related to "expected" answers.

\begin{tabular}{|c|c|c|c|c|c|}
\hline Items & SA & A & $\mathbf{N}$ & $\mathbf{D}$ & SD \\
\hline $\begin{array}{l}\text { 1. Mathematical language allows describing and explaining reality as it is, generating } \\
\text { scientific knowledge. }\end{array}$ & & & & & \\
\hline $\begin{array}{l}\text { 2. In science, it makes no sense to distinguish between theory and observation, since } \\
\text { theory is everywhere in the world. }\end{array}$ & & & & & \\
\hline $\begin{array}{l}\text { 3. In the scientific activity, hypotheses are formulated, then we extract observational } \\
\text { consequences from those hypotheses and we empirically contrast those } \\
\text { observational consequences. }\end{array}$ & & & & & \\
\hline $\begin{array}{l}\text { 4. The choice of a model over another is based not only on the similarity of the } \\
\text { model to the real system, but also on the interests of scientists. }\end{array}$ & & & & & \\
\hline $\begin{array}{l}\text { 5. Scientists accept a theory or a research tradition if they provide a better solution } \\
\text { to empirical and conceptual problems. }\end{array}$ & & & & & \\
\hline 6. Science advances because old theories are falsified and replaced by new theories. & & & & & \\
\hline $\begin{array}{l}\text { 7. In the scientific activity, four contexts are established: } \\
\text { a) Education: related to teaching and dissemination of scientific activity. } \\
\text { b) Innovation: related to inventions and innovation in scientific activity. } \\
\text { c) Assessment: related to progress and improvement of scientific activity. } \\
\text { d) Application: associated with changes in scientific production and artefacts } \\
\text { with the purpose of transforming the environment of scientific activity. }\end{array}$ & & & & & \\
\hline $\begin{array}{l}\text { 8. Scientists performing research start with the observation of phenomena, then } \\
\text { proceed to formulate hypotheses, design and perform experiments, and finally } \\
\text { draw conclusions containing more information than the original hypotheses. This } \\
\text { method is characterized by inductive logic. }\end{array}$ & & & & & \\
\hline $\begin{array}{l}\text { 9. Experimental designs and observations proposed by scientists are mediated by } \\
\text { their scientific models, which also guide decision-making. }\end{array}$ & & & & & \\
\hline
\end{tabular}




\begin{tabular}{|c|c|c|c|c|c|}
\hline Items & SA & A & $\mathbf{N}$ & $\mathbf{D}$ & SD \\
\hline $\begin{array}{l}\text { 10. A scientific theory is a relatively specific set of related doctrines, laws, hypotheses } \\
\text { or principles that are used by scientists to make experimental or observational } \\
\text { predictions and provide explanations for natural phenomena. }\end{array}$ & & & & & \\
\hline $\begin{array}{l}\text { 11. Scientists, working from their theoretical and methodological frameworks, } \\
\text { determine which theory best represents and solves a problem. }\end{array}$ & & & & & \\
\hline $\begin{array}{l}\text { 12. Scientific models are abstract representations of the world, mainly non-linguistic, } \\
\text { with their own internal logic, presenting relationships of similarity with } \\
\text { phenomena and described by specialized symbolic languages. }\end{array}$ & & & & & \\
\hline $\begin{array}{l}\text { 13. A scientific theory solves an empirical problem if the inferred conclusions are } \\
\text { related to statements describing the problem. }\end{array}$ & & & & & \\
\hline $\begin{array}{l}\text { 14. Hypotheses are formulated from a theoretical framework and are corroborated } \\
\text { through the empirical activity of observation and/or experimentation. }\end{array}$ & & & & & \\
\hline $\begin{array}{l}\text { 15. In science, there is no privileged method that scientists have to follow and respect: } \\
\text { they can do and proceed in any way they want, since no method guarantees } \\
\text { success in their scientific activity. }\end{array}$ & & & & & \\
\hline $\begin{array}{l}\text { 16. Truth is understood as the epistemic value that predominates in the scientific } \\
\text { activity. }\end{array}$ & & & & & \\
\hline $\begin{array}{l}\text { 17. In the scientific activity, the relationship between scientific models and experimental } \\
\text { designs is subject to the decisions that scientists make during their research. }\end{array}$ & & & & & \\
\hline $\begin{array}{l}\text { 18. A paradigm constructs an interpretation of the world, thus becoming a possible } \\
\text { truth in science, but paradigms can be modified or replaced by others providing } \\
\text { better solutions to scientific problems. }\end{array}$ & & & & & \\
\hline $\begin{array}{l}\text { 19. Scientific theories are structurally complex entities consisting of general principles } \\
\text { supporting research and innovation, and of a set of experimentally tested } \\
\text { assumptions derived from the general principles. }\end{array}$ & & & & & \\
\hline $\begin{array}{l}\text { 20. Scientists working in a scientific field share assumptions including: theoretical } \\
\text { frameworks, experimental designs, methodological procedures, among other } \\
\text { elements. }\end{array}$ & & & & & \\
\hline $\begin{array}{l}\text { 21. In a mature scientific discipline, a new theory does not only replace the previous } \\
\text { one, but retains what is true in it, perfecting, enriching and extending it. }\end{array}$ & & & & & \\
\hline $\begin{array}{l}\text { 22. Theories or hypotheses are proved or verified when it is possible to carry out } \\
\text { empirical experiments and/or observations in accordance with what is expressed } \\
\text { in them. }\end{array}$ & & & & & \\
\hline $\begin{array}{l}\text { 23. No proposition based on events that occur in nature can be proved through an } \\
\text { experiment. }\end{array}$ & & & & & \\
\hline $\begin{array}{l}\text { 24. Scientists choose theoretical proposals that best fit their models, a choice based on } \\
\text { scientific, social and other interests, with the purpose of interpreting, describing } \\
\text { and explaining the world. }\end{array}$ & & & & & \\
\hline $\begin{array}{l}\text { 25. Theories are composed of statements that explain the world and are refuted or } \\
\text { corroborated based on empirical results. }\end{array}$ & & & & & \\
\hline $\begin{array}{l}\text { 26. After a scientific revolution, scientists see the world differently, meaning that } \\
\text { although the world remains the same, scientists operate in it differently. }\end{array}$ & & & & & \\
\hline $\begin{array}{l}\text { 27. Scientific models mediate between theory and reality. Models allow scientists to } \\
\text { inquire into nature and thus generate explanations for it. }\end{array}$ & & & & & \\
\hline 28. Observation and experimentation provide a solid foundation for scientific inquiry. & & & & & \\
\hline $\begin{array}{l}\text { 29. The acceptance of a new paradigm relies on persuasion techniques, arguments and } \\
\text { counterarguments, in the absence of 'proofs'. }\end{array}$ & & & & & \\
\hline $\begin{array}{l}\text { 30. Scientific advancement is based on the accumulation of theories, whereby new } \\
\text { theories incorporate previous ones both conceptually and methodologically. }\end{array}$ & & & & & \\
\hline $\begin{array}{l}\text { 31. In science, a theory is refuted when the conclusions drawn from it do not } \\
\text { conform to the statements accepted by scientists; this permits to judge that the } \\
\text { theory is wrong. }\end{array}$ & & & & & \\
\hline $\begin{array}{l}\text { 32. The choice of one scientific model over another is due to human interests } \\
\text { (professional, social, etc.); it is a decision that exceeds the interest in just knowing } \\
\text { nature. }\end{array}$ & & & & & \\
\hline
\end{tabular}




\begin{tabular}{|c|c|c|c|c|c|}
\hline Items & SA & A & $\mathbf{N}$ & $\mathbf{D}$ & SD \\
\hline $\begin{array}{l}\text { 33. How theories are discovered is irrelevant, since that depends on varied } \\
\text { circumstances not subject to logical criteria. Instead, it is important to evaluate } \\
\text { procedures by which scientists justify their theories, a task where logic plays a } \\
\text { significant role. }\end{array}$ & & & & & \\
\hline $\begin{array}{l}\text { 34. With theories it is possible to explain, describe and understand the world; } \\
\text { scientists interpret theories as being close to the truth about nature. }\end{array}$ & & & & & \\
\hline 35. Scientists must follow a single epistemic value: truth. & & & & & \\
\hline $\begin{array}{l}\text { 36. Theories are formulated as a system of statements that are susceptible of an } \\
\text { interpretation based on observation and/or experimentation. }\end{array}$ & & & & & \\
\hline $\begin{array}{l}\text { 37. Models can be represented through different symbolic means, allowing us to think, } \\
\text { speak and act on the world of phenomena. }\end{array}$ & & & & & \\
\hline
\end{tabular}

Table 2. Instrument for data collection: Epistemological views on the different topics of the philosophy of science

\section{Results}

Since "the presence of measurement errors in education research is the rule rather than the exception" and the "reliabilities of many measures used in the education sciences are, at best, moderate" (Osborne, 2003), it is important that we take into account the methods accepted in our community to deal with this issue. We chose to analyze the relative reliability of the five response options by computing Spearman rank-order correlation coefficients between the various response options. The assumption was that at least one of the response options would best represent the "true" (i.e. most authentic) answer of each preservice elementary teacher. Therefore, a high correlation coefficient would represent high reliability of all five response options. Likewise, a low correlation coefficient would indicate that one or more response options were less reliable.

Table 3 shows the possible values of the correlations for each pair of variables (combining the five periods and ten topics of the philosophy of science). The established range for the correlation coefficients goes from -1 to +1 . A direct relationship is indicated when the statistic value is positive; when the relationship is inverse, the value is negative. These values determine the strength of the association between variables. We resort to the interpretation of this correlation coefficient proposed by Bisquerra (2009) for the social sciences.

A positive and moderate correlation (according to the ranges in Table 3) between the scores of periods was found in our group of teachers for these pairs: Logical Positivism/Received View-Recent and Contemporary Accounts, and Logical Positivism/Received View-Critical Rationalism; these correlations are significant with a 99\% confidence. The correlations between Logical Positivism/Received View-The New Philosophy of Science and Logical Positivism/Received View-Post-Kuhnian Philosophy of Science were determined to be positive and weak. These correlations show epistemological heterogeneity in teachers.

On the other hand, significant, positive and moderate correlations were determined between Evolution-Logical Positivism/Received View and Evolution-Recent and Contemporary Accounts. Correlations between Intervention-Logical Positivism/Received View and Representation-Logical Positivism/Received View are also highlighted because they are significant, moderate and positive; they are presented in Table 4. In turn, the period of Recent and Contemporary Accounts presents a greater correlation with the topics of Judgment and Rationality. These results allow establishing epistemological trends in teacher's 'eclectic epistemology'.

Data displayed in Table 3 suggest the inference that, as a trend, teachers' views on NOS can be located mainly in two periods of the philosophy of science: Logical Positivism/Received View and Recent and Contemporary Accounts. Such results lead us to consider that teachers hold a consistently classical conception of science that only includes some 'progressive' elements from current philosophy of science. In reference to the aspects of the philosophy of science under consideration, our study determines that prospective teachers' views on Intervention and Representation are strongly linked to Logical 
Positivism/Received View, that is, they are based on the idea that observation and experimentation provide solid foundations for scientific enquiry. These teachers' conception of scientific theories considers them to be composed of statements that explain the world and are strictly refuted or corroborated based on empirical results.

\begin{tabular}{|c|c|}
\hline Coefficient & Relationship interpretation \\
\hline From 0 to 0.20 & Negligible correlation \\
\hline From 0.21 to 0.40 & Weak correlation \\
\hline From 0.41 a 0.70 & Moderate correlation \\
\hline From 0.71 to 0.90 & Strong correlation \\
\hline From 0.91 to 1 & Very strong correlation \\
\hline
\end{tabular}

Source: Bisquerra (2009)

Table 3. Ranges of interpretation for the correlation coefficient

\begin{tabular}{|c|c|c|c|c|c|c|c|c|c|c|c|c|c|c|c|}
\hline & $\begin{array}{l}\text { LP/ } \\
\text { RV }\end{array}$ & $\begin{array}{l}\text { PKP } \\
\text { S }\end{array}$ & CR & $\begin{array}{l}\text { RC } \\
\text { A }\end{array}$ & NPS & $\begin{array}{l}\text { Con } \\
\text { text } \\
\text { s }\end{array}$ & $\begin{array}{l}\text { Corr } \\
\text { espo } \\
\text { nde } \\
\text { nce }\end{array}$ & $\begin{array}{l}\text { Evol } \\
\text { utio } \\
\text { n }\end{array}$ & $\begin{array}{l}\text { Inte } \\
\text { rven } \\
\text { tion }\end{array}$ & $\begin{array}{l}\text { Judg } \\
\text { men } \\
\text { t }\end{array}$ & $\begin{array}{l}\text { Lan } \\
\text { gua } \\
\text { ges }\end{array}$ & $\begin{array}{l}\text { Met } \\
\text { hod } \\
\text { olog } \\
\text { ies }\end{array}$ & $\begin{array}{l}\text { Rati } \\
\text { onal } \\
\text { ity }\end{array}$ & $\begin{array}{l}\text { Rep } \\
\text { rese } \\
\text { ntati } \\
\text { on }\end{array}$ & $\begin{array}{l}\text { Valu } \\
\text { es }\end{array}$ \\
\hline $\mathrm{LP} / \mathrm{RV}$ & 1 & & & & & & & & & & & & & & \\
\hline PKPS & $.453^{* *}$ & 1 & & & & & & & & & & & & & \\
\hline CR & $.481^{* *}$ & $.470^{* *}$ & 1 & & & & & & & & & & & & \\
\hline RCA & $.542^{* *}$ & $.300^{* *}$ & $.329^{* *}$ & 1 & & & & & & & & & & & \\
\hline NPS & $.324^{* *}$ & $.320^{* *}$ & $.340^{* *}$ & $.284^{* *}$ & 1 & & & & & & & & & & \\
\hline Contexts & $.237^{*}$ & 0.081 & 0.074 & $.337^{* *}$ & 0.050 & 1 & & & & & & & & & \\
\hline Correspondence & $.605^{* *}$ & $.506^{* *}$ & $.493^{* *}$ & $.526^{* *}$ & $.421^{* *}$ & 0.026 & 1 & & & & & & & & \\
\hline Evolution & $.548^{* *}$ & $.379^{* *}$ & $.472^{* *}$ & $.480^{* *}$ & $.298^{* *}$ & 0.084 & $.358^{* *}$ & 1 & & & & & & & \\
\hline Intervention & $.577^{* *}$ & $.492^{* *}$ & $.518^{* *}$ & $.429^{* *}$ & $.387^{* *}$ & $.200^{*}$ & $.344^{* *}$ & $.366^{* *}$ & 1 & & & & & & \\
\hline Judgement & $.375^{* *}$ & $.498^{* *}$ & $.274^{* *}$ & $.573^{* *}$ & 0.155 & $.244^{* *}$ & $.301^{* *}$ & $.293^{* *}$ & $.237^{*}$ & 1 & & & & & \\
\hline Languages & $.208^{*}$ & $.360^{* *}$ & $.328^{* *}$ & $.291^{* *}$ & $.273^{* *}$ & 0.046 & $.275^{* *}$ & 0.173 & 0.056 & $.217^{*}$ & 1 & & & & \\
\hline Methodologies & $.534^{* *}$ & $.494^{* *}$ & $.518^{* *}$ & $.434^{* *}$ & $.348^{* *}$ & 0.119 & $.445^{* *}$ & $.278^{* *}$ & $.390^{* *}$ & $.338^{* *}$ & 0.086 & 1 & & & \\
\hline Rationality & $.474^{* *}$ & $.196^{*}$ & $.337^{* *}$ & $.505^{* *}$ & $.186^{*}$ & 0.043 & $.295^{* *}$ & 0.156 & $.367^{* *}$ & $.316^{* *}$ & 0.167 & $.191^{*}$ & 1 & & \\
\hline Representation & $.555^{* *}$ & $.443^{* *}$ & $.471^{* *}$ & $.534^{* *}$ & $.483^{* *}$ & 0.171 & $.463^{* *}$ & $.342^{* *}$ & $.413^{* *}$ & $.272^{* *}$ & 0.183 & $.403^{* *}$ & $.379^{* *}$ & 1 & \\
\hline Values & $.306^{* *}$ & $.189^{*}$ & $.326^{* *}$ & -0.037 & $.310^{* *}$ & -0.151 & 0.131 & 0.181 & $.264^{* *}$ & -0.015 & 0.155 & \begin{tabular}{|l|l|}
-0.018 \\
\end{tabular} & 0.068 & 0.015 & 1 \\
\hline
\end{tabular}

**Correlation is significant at the 0.01 level (bilateral).

*Correlation is significant at the 0.05 level (bilateral).

$\mathrm{N}=114$

Table 4. Correlations between periods and topics

Factor analysis allowed identifying the elements that explain the variability in the measurements obtained for each period and topic of scientific activity. This factor analysis starts from the principle of data reduction and seeks to identify a small number of factors that explain most of the observed variance of a greater number of variables displayed (Lloret-Segura, Ferreres-Traver, Hernández-Baeza \& Tomás-Marco, 2014).

Kaiser-Meyer-Olkin (KMO) criterion for the adequacy of the sample is an index comparing the size of the observed correlation coefficient and the partial correlation coefficient. The KMO rate must be above 0.50. Bartlett's sphericity test, which "consists of a chi-square estimation from a transformation of the 
correlation matrix determinant" (Montoya, 2007: page 284), was used for checking the probability of high rated correlations existence, at least in some of the variables in the correlation's matrix. Results of the KMO test and the Bartlett specificity test are presented in Table 5.

Values obtained indicate that it is suitable to apply factor analysis, since the KMO obtained was 0.61 -well above 0.5-, which is deemed appropriate for social science research (Bryman \& Cramer, 2009; Montoya, 2007). Bartlett's test showed the intercorrelation between the variables. The KMO value that we obtained permits determining a number of components or dimensions that are useful to group periods and topics of the philosophy of science on the basis of similar behavior in front of the variables. In this study, the 'componential' analysis is related to the choices in the group of teachers for some or other of the statements that explicitly connect a period and a topic of the philosophy of science. The analysis technique that we used was Gutman-Kaiser's (Merenda, 1997; Morales-Vallejo, 2013), which proposes as its constitutive parameter the rotation of all factors or variables with eigenvalue over 1 . That is, we take into account factors that, in the 'sedimentation graph', are located over the value 1 . For our analysis, 3 inflection points are assumed (Figure 1); this leads to constructing 3 components/dimensions that provide a fairly adequate solution for our problem, explaining $55.30 \%$ of the total variance.

The first component/dimension explains $25.41 \%$ of the total variance; it is formed by the periods Logical Positivism/Received View, Critical Rationalism and the New Philosophy of Science, alongside with the topics of Intervention, Representation, Methodologies, Evolution and Correspondence (Table 6).

The second component/dimension explains $15.60 \%$ of the total variance, associated with Post-Kuhnian Philosophy of Science and the topic Languages. The third component/dimension explains $14.29 \%$ of the total variance; it is related to the period Recent and Contemporary Accounts (CA) and the topics Contexts, Values and Judgment. A negative score of the topic Values is highlighted.

\begin{tabular}{|l|l|r|}
\hline \multicolumn{2}{|l|}{ Kaiser-Meyer-Olkin Measure of Sampling Adequacy } & 0.651 \\
\hline \multirow{3}{*}{ Bartlett's Test of Sphericity } & chi-square estimate & 1002.973 \\
\cline { 2 - 3 } & Df & 105 \\
\cline { 2 - 3 } & Sig. & 0.000 \\
\hline
\end{tabular}

Table 5. Bartlett's Test and Kaiser-Meyer-Olkin (KMO) measure

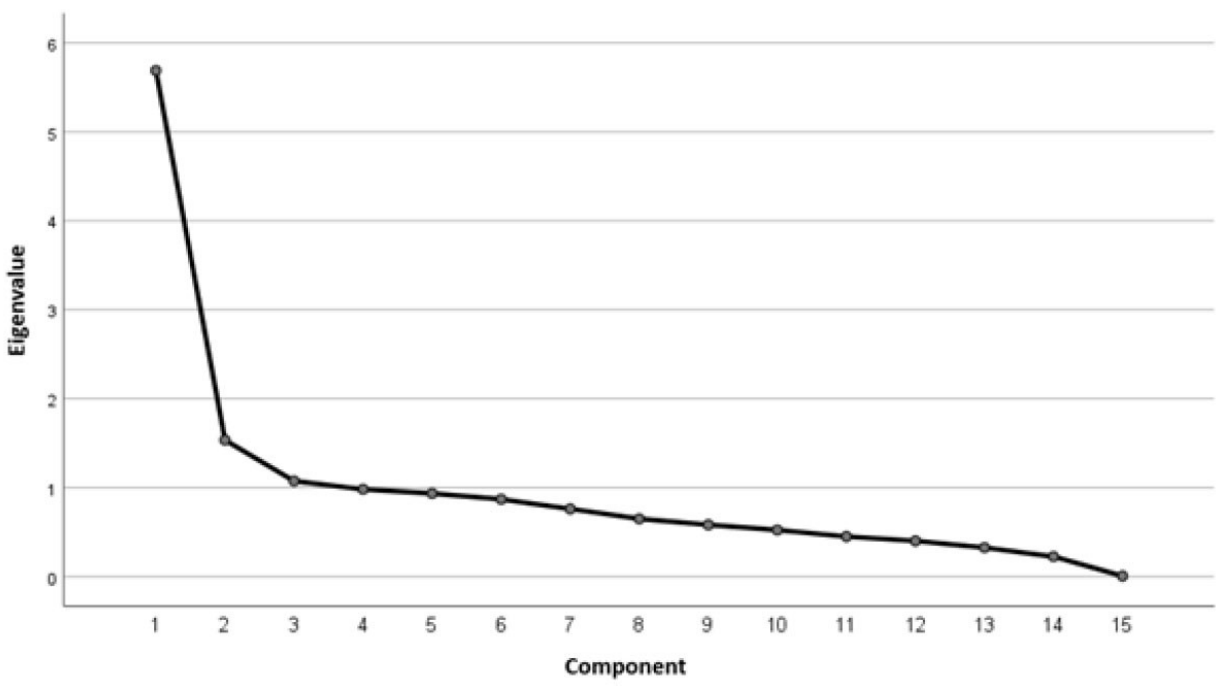

Figure 1. Screen plot 
The three previous components/dimensions can be interpreted as unobservable variables; they are formulated statistically from strong correlations between periods and aspects of the philosophy of science. In this sense, factorial scores made it possible to link subjects in our study with profiles that combine philosophical periods and aspects (Table 7).

These analyses allow the proposal of three teacher profiles (Tables 7 and 8). Each profile is not linked to a single period; thus, the reported existence of eclectic epistemological conceptions on NOS is confirmed for our teachers. The first teacher profile is associated with three periods (Critical Rationalism, Logical Positivism/Received View, the New Philosophy of Science) strongly related to the topics of

Methodologies, Intervention and Values. The second profile is associated with Post-Kuhnian Philosophy of Science and the topics Languages and Values. The last profile is related to Recent and Contemporary Accounts and the topics of Judgment and Contexts. It is worth noting that the analyses that we carried out determined that the topic of Rationality is not associated with a definite epistemological position in our teachers.

\begin{tabular}{|c|c|c|c|}
\hline \multirow[b]{2}{*}{ Variable } & \multicolumn{3}{|c|}{ Component/Dimension } \\
\hline & 1 & 2 & 3 \\
\hline Intervention & 0.786 & & \\
\hline $\mathrm{LP} / \mathrm{RV}$ & 0.745 & & \\
\hline $\mathrm{CR}$ & 0.659 & & \\
\hline Representation & 0.571 & & \\
\hline NPS & 0.547 & & \\
\hline Methodologies & 0.534 & & \\
\hline Evolution & 0.530 & & \\
\hline Correspondence & 0.513 & & \\
\hline Languages & & 0.875 & \\
\hline PKPS & & 0.595 & \\
\hline RCA & & & 0.683 \\
\hline Contexts & & & 0.629 \\
\hline Values & & & -0.576 \\
\hline Judgment & & & 0.575 \\
\hline Rationality & - & - & - \\
\hline
\end{tabular}

Extraction method: principal component analysis.

Rotation method: Equamax with Kaiser normalization.

Table 6. Rotated Factor Matrix

\begin{tabular}{|c|r|r|r|r|}
\hline \multirow{2}{*}{ Profile } & \multicolumn{3}{|c|}{ Average Z Score: } & \multirow{2}{*}{ N } \\
\cline { 2 - 5 } & Dimension 1 & Dimension 2 & Dimension 3 & \multicolumn{1}{c|}{ N } \\
\hline Profile 1 & $\mathbf{0 . 8 1}$ & -0.43 & -0.38 & 36 \\
\hline Profile 2 & -0.18 & $\mathbf{0 . 7 9}$ & -0.48 & $\mathbf{0 . 7 3}$ \\
\hline Profile 3 & -0.54 & -0.31 & $\mathbf{0 . 7 3}$ \\
\hline
\end{tabular}

Table 7. Teachers' NOS profiles 


\begin{tabular}{|l|r|r|r|}
\hline \multirow{2}{*}{\multicolumn{1}{c|}{ Period/topic }} & \multicolumn{3}{|c|}{ Profile } \\
\cline { 2 - 4 } & \multicolumn{1}{c|}{$\mathbf{1}$} & \multicolumn{1}{c|}{$\mathbf{2}$} & \multicolumn{1}{c|}{$\mathbf{3}$} \\
\hline RCA & -0.23 & 0.04 & $\mathbf{0 . 1 7}$ \\
\hline CR & $\mathbf{0 . 4 1}$ & 0.21 & -0.53 \\
\hline LP/RV & $\mathbf{0 . 3 9}$ & -0.16 & -0.20 \\
\hline PKPS & 0.15 & $\mathbf{0 . 2 1}$ & -0.31 \\
\hline NPS & $\mathbf{0 . 2 9}$ & 0.19 & -0.41 \\
\hline Methodologies & $\mathbf{0 . 3 5}$ & -0.17 & -0.15 \\
\hline Languages & -0.43 & $\mathbf{0 . 7 3}$ & -0.26 \\
\hline Judgment & -0.36 & 0.12 & $\mathbf{0 . 2 1}$ \\
\hline Intervention & $\mathbf{0 . 5 9}$ & -0.24 & -0.31 \\
\hline Evolution & 0.25 & -0.01 & -0.20 \\
\hline Correspondence & 0.18 & 0.16 & -0.29 \\
\hline Contexts & -0.13 & -0.48 & $\mathbf{0 . 5 2}$ \\
\hline Values & $\mathbf{0 . 4 4}$ & $\mathbf{0 . 4 4}$ & -0.75 \\
\hline Representation & 0.04 & 0.05 & -0.07 \\
\hline Rationality & 0.09 & 0.05 & -0.12 \\
\hline
\end{tabular}

Table 8. Scores for teachers' NOS profiles

\section{Discussion}

Findings in this study match previous reports (Martínez \& González, 2014; Porlán \& Martín del Pozo, 2002) of the existence of a diversity in epistemological views in teachers. We have established different 'eclectic' NOS positionings in our sample, beyond the classical category of 'intermediate' or 'has merit' view (Dogan \& Abd-El-Khalick, 2008). Participants' conceptions of NOS are not homogeneous, i.e., they lack coherence throughout the ten topics of the philosophy of science.

The concept of 'epistemological profile' was proposed by Gaston Bachelard (1940), in his book La philosophie du "non": Essai d'une philosophie du nouvel esprit scientifique; it is defined as the diversity of epistemological positions that a subject maintains with respect to the nature of knowledge. Bachelardian profiles are analyzed in relation with different epistemological topics, emphasizing that people's thinking is not homogeneous and that subjects use different approaches for the same conceptual entity. Our own proposal of three 'epistemological profiles' for student teachers enrolled in programs of Primary Education intends to give a more detailed account than those already available of the epistemological conceptions of the nature of science, by relating those conceptions to five periods and ten topics from the philosophy of science.

\subsection{Teachers in Profile 1}

Teachers in this profile would adhere to the idea that observation and experimentation in science can be performed before formulating any theory or model. They agree on the existence of a method as a set of linearly-followed steps; such a method is composed of observation, construction of hypotheses, experiment, and statement of conclusions. These teachers also believe that scientific theories depict how the world functions. They deem that the evolution of science is the result of a linear and cumulative growth.

This profile is also related to the idea that knowledge is found in reality, and that science is a faithful reflection of it. These pre-service teachers think that scientists collect their data through a scientific method that uses observation and experimentation as guides for discovery. This conception is supported by classical epistemic values such as truth. 
Teachers in training who belong to this profile distance themselves from the idea that values of science relate to axiological criteria of social nature, such as that results of the scientific activity must be public, communicable and teachable, or that scientific knowledge must be accessible to any human being. They also move away from the idea of a 'temperate' conception of the methodology of science that focuses on the ability to think about the world with theoretical models, to generate abstract languages to create and communicate knowledge, and to intervene on phenomena in a transformative way.

\subsection{Teachers in Profile 2}

Derek Hodson (2009) proposes that a mastery of the technical language of science is necessary to share scientific experiences and knowledge with others, and that language also allows scientists to approach problems, formulate and evaluate solutions, critique the proposed formulations, and make consensus-based decisions on scientific issues. It is likely that teachers in this profile think that an empirical problem is solved in science by the proposal of a theory. From such a theory, a particular scientific statement can be derived that serves as an approximate solution to the problem.

This epistemological profile is related to the idea that scientific terms are theory-laden, and that all observations depend on the theory through which the world is observed. Philosophical ideas preferred by teachers in this profile indicate that theories 'determine' the nature of the observational terms used.

\subsection{Teachers in Profile 3}

Teachers in this profile recognize the existence of different contexts in science. They focus on the application and usefulness of innovations in science and judge the advancement of the scientific activity in terms of its possible benefits or harms to society. They also bring to the forefront the idea of scientific models, believing that there are criteria to assess the quality of those models; such criteria do not exclusively appeal to models 'fitting' to the world. Nothing in the world completely determines the aspects and grades to be modelled.

This teacher profile agrees with the idea that science is a human activity in which many factors intervene; one of these is education and dissemination of scientific knowledge. Teachers in this profile adhere to a reconstruction of the scientific activity in terms of problem solving: scientists develop more or less innovative theoretical models with the aim of facing well-characterized challenges of in our relationship with the natural world.

\section{Conclusions}

In this study, the combined use of periods and topics of the philosophy of science was introduced with the intention of providing a more nuanced depiction of science teachers' ideas on NOS. This tool aimed at obtaining higher conceptual sophistication in the analysis. Mapping teachers' views to a periodized network of philosophical conceptions permitted introducing specific epistemological content that was not explicitly considered in previous research on NOS.

Results with this new tool show that we cannot construct 'general' trends in teachers' NOS, since very different epistemological views emerge in relation to the different topics and periods. Depending on the epistemological statements on which we choose to focus, we can locate teachers near Logical Positivism/Received View or the New Philosophy of Science. And, with respect to particular epistemological aspects of scientific practice, some of our teachers express views that can be located next to some formulations of Recent and Contemporary Accounts.

The present study shows that we cannot characterize teachers' NOS as belonging 'en bloc' to Logical Positivism and the Received View for all epistemological topics, in opposition to what was reported in other studies. Teachers' NOS seems to be more complex; a conclusion also shared by Vicente Mellado (1997). It should be noted that each of the three epistemological profiles that we have proposed in this study cover a variety of students in teacher training in terms of age, gender and socio-economic 
background. Nevertheless, in future investigations, these could be variables to consider in order to identify possible correlations with NOS. So far as our sample has permitted, epistemological profiles seem to be more related to previous educational experiences.

As for the proposed topics of the philosophy of science, they were shown to constitute a robust framework to organize epistemological claims and characterize subjects' views on NOS, given its specificity regarding the different aspects of scientific activity. In this line, results allow supporting our conclusion that future teachers' views on NOS are diverse (and even dispersed). There is a clear basis of a strongly traditional view, but many elements do not point towards a precise period.

In this sense, the 'conservative' hypothesis presented at the beginning of this study does not hold with our participants -they cannot be easily typified as positivistic. Instead, they are -as many other studies have shown- epistemologically eclectic, and this eclecticism can be examined in detail with respect to specific periods and topics of the philosophy of science. It is also worth noting the timid presence -among the prospective teachers that we examined- of epistemological views that can be associated with recent formulations of the philosophy of science, and in particular with a model-based view of science. This is encouraging, and a possible entry point for more epistemologically adequate efforts in teacher education around NOS.

\section{Declaration of Conflicting Interests}

The authors declared no potential conflicts of interest with respect to the research, authorship, and/or publication of this article.

\section{Funding}

The authors received no financial support for the research, authorship, and/or publication of this article.

\section{References}

Abd-El-Khalick, F.S., \& Lederman, N.G. (2000). Improving science teachers' conceptions of the nature of science: A critical review of the literature. International Journal of Science Education, 22, 665-701. https://doi.org/10.1080/09500690050044044

Adúriz-Bravo, A. 2013). A 'Semantic’view of scientific models for science education. Science \& Education, 22 (7), 1593-1611. https://doi.org/10.1007/s11191-011-9431-7

Adúriz-Bravo, A. (2014). Teaching the Nature of Science with Scientific Narratives. Interchange, 45, 167-184. https://doi.org/10.1007/s10780-015-9229-7

Adúriz-Bravo, A \& Izquierdo-Aymerich, M. (2009). Un modelo de modelo científico para la enseñanza de las ciencias naturales. Revista electrónica de investigación en educación en ciencias, 4(3), 40-49.

Akerson, V.L., \& Donnelly, L.A. (2008). Relationships among learner characteristics and preservice elementary teachers' views of nature of science. Journal of Elementary Science Education, 20(1), 45-58. https://doi.org/10.1007/BF03174702

Amador-Rodríguez, R.Y. (2018). La Naturaleza de la Ciencia Representada en Libros de Texto de Química Latinoamericanos. Tesis doctoral. Universidad Nacional del Comahue, Neuquén - Argentina.

Amador-Rodríguez, R.Y., \& Adúriz-Bravo, A. (2018). Consensus and Dissent Around the Concept of Nature of Science in the Ibero-American Community of Didactics of Science. In Teacbing Science with Context (31-47). Cham: Springer. https://doi.org/10.1007/978-3-319-74036-2_3

Bachelard, G. (1940) La philosophie du "non": Essai d'une philosophie du nouvel esprit scientifique. Avantpropos, Paris: PUF. 
Bisquerra, R. (2009). Metodología de la investigación educativa. Madrid, España: La muralla.

Bryman, A., \& Cramer, D. (2009). Quantitative data analysis with SPSS 14, 15 \& 16: A guide for social scientists. Routledge/Taylor \& Francis Group.

Buaraphan, K. (2012). Embedding Nature of Science in Teaching About Astronomy and Space. Journal of Science Education and Technology, 21, 353-369. https://doi.org/10.1007/s10956-011-9329-9

Cleminson, A. (1990). Establishing an epistemological base for Science teaching in the light of contemporary notions of the nature of Science and of how children learn Science. Journal of Research in Science Teaching, 27(5), 429-445. https://doi.org/10.1002/tea.3660270504

Colagrande, E.A., Martorano, S.A.A., \& Arroio, A. (2016). Assessment on How Pre-Service Science Teachers View the Nature of Science. Journal of Turkish Science Education, 13(4),293-307 http://www.tused.org

Dogan, N., \& Abd-El-Khalick, F. (2008). Turkish grade 10 students' and science teachers' conceptions of nature of science: A national study. Journal of Research in Science Teaching, 45(10), 1083-1112. https://doi.org/10.1002/tea.20243

Flick, L. \& Lederman, N.G. (Eds.) (2004). Scientific inquiry and nature of science: implications for teaching, learning, and teacher education. Dordrecht, The Netherlands: Kluwer Academic Publishers.

Gallagher, J.J. (1991). Perspective and practicing secondary school science teachers' knowledge and beliefs about the philosophy of science. Science Education, 75, 121-134. https://doi.org/10.1002/sce.3730750111

Hodson, D. (2009). Teaching and learning about science: Language, theories, methods, history, traditions and values. Brill Sense. https://doi.org/10.1163/9789460910531

Irzik, G., \& Nola, R. (2011). A family resemblance approach to the nature of science for science education. Science \& Education, 20(7-8), 591-607. https://doi.org/10.1007/s11191-010-9293-4

Izquierdo-Aymerich, M., \& Adúriz-Bravo, A. (2003). Epistemological foundations of school science. Science \& Education, 12(1), 27-43. https://doi.org/10.1023/A:1022698205904

Jun-Young, O.H., \& Lederman, N.G. (2018). Using an Explicit NOS Flow Map in Instruction of Nature of Science Based on the Science of Philosophy. Journal of Turkish Science Education, 15(3), 64-90. http://www.tused.org

Klopfer, L.E. (1969). The teaching of science and the history of science. Journal of Research for Science Teaching, 6, 87-95. https://doi.org/10.1002/tea.3660060116

Lederman, N.G. (1999). Teachers' understanding of the nature of science and classroom practice: Factors that facilitate or impede the relationship. Journal of Research in Science Teaching, 36(8), 916-929. https://doi.org/10.1002/(SICI)1098-2736(199910)36:8<916::AID-TEA2>3.0.CO;2-A

Leinonen, R., Haaranen, M., Kesonen, M., Koponen, M., Hirvonen, P.E., \& Asikainen, M.A. (2020). Finnish graduated physics teachers' views about their teacher education program: The disparity between the needs and delivery. Journal of Technology and Science Education, 10(1), 101-116.

https://doi.org/10.3926/jotse.820

Lin, H.S., \& Chen, C.C. (2002). Promoting preservice chemistry teachers' understanding about the nature of science through history. Journal of Research in Science Teaching, 39(9), 773-792.

https://doi.org/10.1002/tea.10045

Lloret-Segura, S., Ferreres-Traver, A., Hernández-Baeza, A., \& Tomás-Marco, I. (2014). El Análisis Factorial Exploratorio de los Ítems: una guía práctica, revisada y actualizada. Anales de Psicología, 30(3), 1151-1169. https://dx.doi.org/10.6018/analesps.30.3.199361 
Martínez, C.P., \& González, C.U. (2014). Concepciones del profesorado universitario acerca de la ciencia y su aprendizaje y cómo abordan la promoción de competencias científicas en la formación de futuros profesores de Biología. Enseñanza de las ciencias, 32 (1), 51-81.

http://dx.doi.org/10.5565/rev/ensciencias. 852

Matthews, M.R. (2012). Changing the focus: From nature of science (NOS) to features of science (FOS). In Advances in nature of science research (3-26). Springer Netherlands. https://doi.org/10.1007/978-94-007-2457-0_1

McComas, W.F. (1996). Ten myths of science: Reexamining what we think we know about the nature of science. School Science and Mathematics, 96, 10-16. https://doi.org/10.1111/j.1949-8594.1996.tb10205.x

McComas, W.F., Almazroa, H. \& Clough, M.P. (1998). The Nature of Science in Science Education: An Introduction. Science \& Education, 7, 511-532. https://doi.org/10.1023/A:1008642510402

Mellado, V. (1997). Preservice teachers 'classroom practice and their conceptions of the nature of science. Science \& Education, 6(4), 331-354. https://doi.org/10.1023/A:1008674102380

Mellado, V. \& Carracedo, D. (1993). Contribuciones de la filosofía de la ciencia a la didáctica de las ciencias. Enseñanza de las ciencias, 11(3), 331-339. https://doi.org/10.5565/rev/ensciencias.4514

Merenda, P.F. (1997). A guide to the proper use of factor analysis in the conduct and reporting of research: Pitfalls to avoid. Measurement and Evaluation in counseling and Development, 30(3), 156-164. https://doi.org/10.1080/07481756.1997.12068936

Montoya, O.M. (2007). Aplicación del análisis factorial a la investigación de mercados. Caso de estudio. Scientia et technica, 1(35). http:/ / dx.doi.org/10.22517/23447214.5443

Morales-Vallejo, P. (2013). El análisis factorial en la construcción e interpretación de tests, escalas y cuestionarios. Madrid, España: Universidad Pontificia Comillas.

Morrison, J., Raab, F., \& Ingram, D. (2009). Factors influencing elementary and secondary teachers' views on the nature of science. Journal of Research in Science Teaching, 46(4), 384-403.

https://doi.org/10.1002/tea.20252

National Science Teachers Association (1982). Science-technology-society: Science education for the 1980s. (An NSTA position statement). Washington, DC.

Nussbaum, J. (1983). Classroom conceptual change: The lessons to be learned from the History of Science. In Helm, H., \& Novak, J. (Eds.), Misconceptions in Science and Mathematics (272-281). Ithaca: Cornell University.

Osborne, J.W. (2003). Effect sizes and the disattenuation of correlation and regression coefficients: Lessons from educational psychology. Practical Assessment, Research \&Evaluation, 8(11), 1-5. https://doi.org/10.7275/0k9h-tq64

Porlán, P., \& Martín del Pozo, R (2002). Spanish Teachers' Epistemological and Scientific Conceptions: Implications for teacher education1. European Journal of Teacher Education, 25(2-3), 151-169. https://doi.org/10.1080/0261976022000035683

Prima, E.C., Utari, S., Chandra, D.T., Hasanah, L., \& Rusdiana, D. (2018). Heat and temperature experiment designs to support students' conception on nature of science. Journal of Technology and Science Education, 8(4), 453-472. https://doi.org/10.3926/jotse.419

Ryan, A.G., \& Aikenhead, G.S. (1992). Students' preconceptions about the epistemology of science. Science Education, 76, 559-580. https://doi.org/10.1002/sce.3730760602 
Sevim, S., \& Pekbay, C.A. (2012). A study toward teaching the nature of science to preservice teachers. Journal of Turkish Science Education, 9(3), 207-227. http://www.tused.org

Torres, J., Moutinho, S., Almeida, A., \& Vasconcelos, C. (2013). Portuguese science teachers' views about nature of science and scientific models. Enseñanza de las ciencias, Extra, 3541-3546.

Tsai, C.C., \& Liu, S.Y. (2005). Developing a multi-dimensional instrument for assessing students' epistemological views toward science. International Journal of Science Education, 27, 1621-1638. https://doi.org/10.1080/09500690500206432

Ucar, S. (2012). How Do Pre-Service Science Teachers' Views on Science, Scientists, and Science Teaching Change Over Time in a Science Teacher Training Program? Journal of Science Education and Technology, 21, 255-266. https://doi.org/10.1007/s10956-011-9311-6

Published by OmniaScience (www.omniascience.com)

Journal of Technology and Science Education, 2021 (www.jotse.org)

\section{(c) (1) (\$)}

Article's contents are provided on an Attribution-Non Commercial 4.0 Creative commons International License. Readers are allowed to copy, distribute and communicate article's contents, provided the author's and JOTSE journal's names are included. It must not be used for commercial purposes. To see the complete licence contents, please visit https://creativecommons.org/licenses/by-nc/4.0/. 